\title{
Reference to International Evaluation Standards for Improving Yunnan Higher Education in Tourism
}

\author{
Yu Liu ${ }^{1}$ and Hao Lin ${ }^{1, *}$

\begin{abstract}
${ }^{1}$ Humanities and Social Sciences College, Yunnan Agricultural University, Kunming, Yunnan 650221, China
*Corresponding author.Email: linhao@ynufe.edu.cn
\end{abstract}

\begin{abstract}
This paper aims to substantiate and make some suggestions for improving the general level of Yunnan higher education in tourism. By analyzed phenomenon of Yunnan higher education in tourism, compared standards between National Standard for Teaching Quality of Tourism Management (NSTQTM) and the Association to Advance Collegiate Schools of Business International (AACSBI), the European Quality Improvement System (EQUIS), took tourism department of Yunnan Agriculture University as example, it has been clearly found that Yunnan higher education in tourism must establish scientific expertise and technical modules. This could be done by integrating domestic and foreign education resources in tourism, which could in turn achieve international standards and meet the needs of tourism industry development.
\end{abstract} Keywords: higher education in tourism, Yunnan, NSTQTM, AACSBI, EQUIS

\section{INTRODUCTION}

Tourism is one of the most favorable and largest industries in the global economic system, because it has the dual role of the promotion of economic growth and the distribution of national wealth. The development of tourism not only directly aids to the interests of tourists and the people of the host countries but is also conducive to the economic development in the region, it also promotes the development of other local industries with the leading role of tourism.

Yunnan Province is located at the junction of China, South Asia and Southeast Asia. It is not only a major tour destination in China, but also a bridge and window for cross-border tourism between Yunnan, South Asian and Southeast Asian countries. In 2016, there were 37.17 million inbound and outbound passengers in Yunnan, including 11.816 million inbound and outbound tourists; and about two million overnight tourists from South and Southeast Asian countries visited Yunnan.[1]Seven of the top ten destination countries for Chinese tourists in 2018 were from member countries of the Association of South East Asian Nations (ASEAN).[2] Under the China-ASEAN and Greater Mekong Sub-regional Tourism Cooperation Framework Agreement, regional tourism cooperation has been steadily advanced, and the building of border tourism pilot zones and cross-border tourism cooperation zones have been actively promoted.[3]

However, tourism transactions as well as cross-regional and cross-cultural development depend on the education level of tourism talents. Therefore, relying on universities and colleges to set up a national tourism talent training base is conducive to meeting the needs of tourism cooperation among regional countries and to supporting national tourism competitiveness.[4] Therefore, it requires that higher education in tourism must be continuously improved and adapted to the requirements of the industry's development.

In 2015, a proposal that Yunnan should be built as a radiation center for South and Southeast Asia was indicated by the central government.[5] In 2015, the proposal: "Building a South and Southeast Asia Radiation Center", meant that Yunnan higher education should provide more professional and international talents, to meet the needs of internationalization growth within the tourism industry. Higher education in tourism, as the education base for training tourism management talents must meet the requirements from the central government on improving the international education mechanism, as well as keeping pace with the speed of the economic and social developments in Yunnan.

\section{LITERATURE REVIEW ON PROBLEMS IN CHINA HIGHER EDUCATION IN TOURISM}

\subsection{Although the Tourism Industry Continues to Develop at High Speed and with New Models, Higher Education in Tourism still Lags Behind Industry Growth.}

China's higher education in tourism started late. With the rapid development of new forms of tourism, talent education has become less and less able to keep up with the demand for talents along with development pace of the tourism industry. It has not been able to cultivate comprehensive talents that meet the needs of the industry growth. Curriculum settings, teaching plans, teaching 
methods, internship arrangements, teachers, etc. are seriously out of touch with the demands of the industry and with society.[6] The boundaries of sub-specialities such as hotel management, tourism management, exhibition tourism, leisure management or tourism planning are unclear. Teaching plans, teaching methods, and curriculum settings are overly homogenized.[7]

\subsection{Unprofessional Teachers and Lack of High-Quality Teachers Are Common Problems in Higher Education within Tourism.}

Teachers are unprofessional, they lack industry background and their knowledge is outdated. Besides, most of the tourism departments were started based on departments with different academic backgrounds unrelated to tourism such as foreign languages, geography, Chinese and humanities. Teaching teams have been shifted from their original departments to the tourism department, and have had weak professional knowledge and poor consciousness of management, business, finance, etc.. Moreover, most teachers don't have professional experience in the tourism industry, which means that lack of qualified tourism educators has been a widespread problem.[8] The teaching teams in university and college is obviously lagging behind the development of the industry.[9][10][11] It is quite common for teachers to use the same in-depth textbooks to teach different tourism sub-specialized courses.[12][13]

\subsection{Higher Education in Tourism for Talents Is still at a Fragmented Level with Weak Organization and Continuity.}

In view of the problems existing in tourism higher education, series of reforms and countermeasures guided by the government have been taken, such as establishing a synergistic platform to integrate different social divisions, establishing a coordination mechanism between university and industry,[6] making efforts to establish a long-term mechanism of school-enterprise cooperation, building a practical education system, building a ladder for improving students' practical ability, building a collaborative schoolenterprise education mechanism,[14] building a "Four-inOne" curriculum system on the dimensions of theory, literacy, technology, and practice, and promoting the teaching reform innovation mechanism.[15] Although social sectors have taken some measures to solve the contradiction between the effective supply and demand of professional talents, the existing problems of high education in tourism still fundamentally have not been solved.

\section{PROBLEMS FACED BY YUNNAN HIGHER EDUCATION IN TOURISM.}

Before you begin to format your paper, first write and save the content as a separate text file. Keep your text and graphic files separate until after the text has been formatted and styled. Do not use hard tabs, and limit use of hard returns to only one return at the end of a paragraph. Do not add any kind of pagination anywhere in the paper. Do not number text heads-the template will do that for you.

Finally, complete content and organizational editing before formatting. Please take note of the following items when proofreading spelling and grammar:

\subsection{The General State of Yunnan Higher Education in Tourism.}

Yunnan higher education in tourism started in 1986. Now, there are a total of sixteen schools teaching tourism. The education objectives have moved focus from cultivating foreign language translators and tour guides, to training comprehensive tourism management talents. Yunnan high education in tourism has recently formed a multi-level education degree at undergraduate and post-graduate level, shifting the depth from quantity to quality. However, like other domestic tourism colleges and universities, Yunnan higher education in tourism also has had problems such as a lack of connection with the industry, an outdated teaching system, weak teaching staff, and low employment rate.[16] The tourism industry in Yunnan has also faced the serious challenge of a lack of internationalization talents.[17] Along with the rapid growth of the industry, the shortage of professional tourism talents has become more and more prominent.[18] Insufficient effective supply for tourism talents and shortage of international tourism talents has caused serious problems in higher education. [ 19 ] Obviously, Yunnan high education in tourism has restricted the growth of the tourism industry in Yunnan and hindered the opening-up to South and Southeast Asia.

In order to meet the requirements of Yunnan's economic and social development, improve the quality of talent training and serve the modernization development of Yunnan, Yunnan Provincial Department of Education has initiated a comprehensive evaluation of undergraduate majors since 2018, which is conducted once a year. The evaluation focuses on five indicators: courses, teachers, teaching materials, tests and employment. It has been divided into four levels: A, B, C and D. A, is the best, followed by $\mathrm{B}, \mathrm{C}$ is qualified, and $\mathrm{D}$ is unqualified. 
Table 1 List of sixteen universities teaching tourism with their comprehensive evaluation level in 2021

\begin{tabular}{|l|c|c|}
\hline \multirow{2}{*}{ No. } & University and its Evaluation Level \\
\cline { 2 - 3 } & University & Level \\
\hline 2 & Yunnan University & B \\
\hline 3 & Yunnan University of Finance and \\
Economics & C \\
\hline 4 & Kunming University & C \\
\hline 5 & Yunnan Normal University & C \\
\hline 6 & Yunnan Minzu University & C \\
\hline 7 & Yunnan Agricultural University & C \\
\hline 8 & Southwest Forestry University & C \\
\hline 9 & Yuxi Normal University & C \\
\hline 10 & The college of Arts and Science Kunming & C \\
\hline 11 & Dali University & C \\
\hline 12 & Kunming City College & D \\
\hline 13 & Dianchi College & D \\
\hline 14 & Baoshan University & D \\
\hline 15 & Zhaotong University & D \\
\hline 16 & Yunnan University & B \\
\hline 0 & Culture and Tourism College & C \\
\hline
\end{tabular}

One university has been rated as B and most of universities as $\mathrm{C}$, which meant the teaching qualities of most of universities in Yunnan just reached at qualified level, the bottom line of higher education in tourism.

Currently, the tourism industry in Yunnan coincides with the national strategic layout of the "One-Belt-One-Road" initiative as well as "Building a South and Southeast Asia Radiation Center" proposed by the central government. It has brought new development opportunities to the tourism industry in Yunnan province. Yunnan higher education in tourism should take this opportunity to accelerate the opening-up to the outside world by strengthening the integration of domestic and foreign education resources, thus comprehensively improve its overall quality and competitiveness.[18] Improving the teaching quality and international level of Yunnan higher education in tourism has become critical and urgent at this moment.

\subsection{Tourism Management Education in Yunnan Agricultural University (YAU)}

Tourism management education in YAU was started in 2000. It has nearly 5,000 graduates. Like most of universities teaching tourism, YAU was rated $\mathrm{C}$ level in comprehensive evaluation in 2021. There are total thirteen teachers in the teaching team, including two Ph.D. and eleven master. Three teachers had overseas education background, one had industry working experience. Main courses are principles of management, project management, economics, introduction to tourism, human resource development and management, tourism geography, tourism resources, tourism marketing, tourism planning and development, introduction to hotel management, travel agency management, tourism psychology, tour guide business, tourism financial management. Internship practice in tourism industry for half year are required in hotel, amusement parks before student graduation. There were average about $30 \%$ students working in the tourism industry after graduation in recent ten years.

\section{COUNTERMEASURES FOR IMPROVING YUNNAN HIGHER EDUCATION IN TOURISM IN REFERENCE TO INTERNATIONAL STANDARDS.}

China's higher education is built in accordance with the unified national standards, and the majors of each university must meet the basic requirements from China Ministry of Education. That is the basic basis for each college and university on setting up majors, formulating professional talent training standards and revising talent training programs. Tourism major in each university and college in Yunnan is built and run in the guidance of the national standard.

\subsection{NSTQTM, AACSBI and EQUIS}

The template is designed so that author affiliations are not repeated each time for multiple authors of the same affiliation. Please keep your affiliations as succinct as possible (for example, do not differentiate among departments of the same organization). This template was designed for two affiliations.

\subsubsection{NSTQTM}

In 2018, the Ministry of Education in China promulgated the NSTQTM, which clarified the basic requirements to higher education in tourism, which is the guidance of establishment and development for undergraduate higher education in tourism. NSTQTM includes eight parts, on overview, main scope of application, training objectives, specifications of training, curriculum systems, teachers, teaching conditions, teaching effects and quality management.[20]

In addition, NSTQTM has also been used as the evaluation criteria on teaching quality. It has been used as the base of the professional accreditation to tourism colleges and universities. Based on NSTQTM, Chinese professional accreditation has focused on five areas: achieving professional development goals and education outcomes, professional positioning and meeting social needs, supporting teachers and teaching resources, operational 
effectiveness of the quality assurance system, and student and employer satisfaction.[21]

\subsubsection{AACSB and EQUIS}

As the world's authoritative accreditation system, AACSB known as the North American System, and EQUIS known as the European Quality Improvement System, as quality criteria serves for both of business industry and education field.

There are four main categories in AACSB: management and innovation, participant: faculty, and professional staff, learning and teaching, and finally academic and professional participation.[22] While EQUIS standards are divided into four main components: context, governance and strategy, quality of the school's resources and operations, internationalization, corporate connections and ethics, responsibility \& sustainability, and executive education.[23]

\subsubsection{Comparison between NSTQTM and $A A C S B, E Q U I S$}

When comparing the differences of the standard between China's universities and colleges in tourism with other countries', it is not difficult to find that AACSB and EQUIS play active and effective roles in the guidance for the establishment of professional higher education in these schools. The curriculum modules set up by these schools obviously have the characteristics of being oriented on business knowledge, technology applications, enterprise connections, internationalization, and keeping up the growth in industry and community. However, in the NSTQTM, higher education in tourism has not had significantly created close ties with the tourism industry and society. For example, in YAU, the connection between education and tourism has mainly been achieved through the students' half-year industry internship. Industry experts come to the school to give very few speeches. Students acquire knowledge through theoretical study in the classroom. The close connection between the education profession and industry, society have not received the attention they deserve.

In the AACSB, the module of general skill and knowledge has been listed for eight criteria, which are effective communication in oral and writing, understanding and reasoning ethical issues and addressing the issues in a socially responsible manner, analyzing and framing problems in an analytic way, working effectively with others and in team environments, working effectively in diverse environments, understanding oneself in the context of society in a reflective way, applying knowledge, and the integration of real world business experiences.[22] These criteria have stressed the development of talent, but in NSTQTM, insufficient attention has been paid to the cultivation of this kind of person's ability. For example, in YAU, in the guidance of NSTQTM, the general course module consists public compulsory course module and student quality development course module. Public compulsory course module includes an introduction to primary principles of Marxism, Mao Zedong thought, the theoretical system of socialism with Chinese characteristics, outline of China's modern history, ideological and moral cultivation and legal concept, situation and policy, computer science, foreign language, etc. Student quality education course module includes humanities and social sciences, natural sciences, art, innovation and entrepreneurship, etc. In YAU, no specific courses, for developing student's social skills such as on speaking and writing, or improving student's working abilities such as applying knowledge to real world job, have been set.

Although there are some similar aspects between NSTQTM and AACSB on emphasizing the understanding of ethical issues, social responsibility, and approaches in terms of course design in the general course module, big differences still exist. For example, AACSB has highlighted more practical practices than NSTQTM in areas such as communication, writing, social connections, teamwork, and productivity in complex environments, which help developing student's character and real-world job skills. In NSTQTM, the specific courses within its education framework for developing student's character and real-world job skills have not been clearly elaborated upon, which has resulted in a different interpretation and understanding of quality education from each school. In YAU, group discussions, classroom presentations, the invitation of guest speaker from industry have been applied in class, which have been considered as actions of developing student abilities on communication, team work, social connections as well as cultivating student's characters and real-world job skills. Although these methods have partially improved student's abilities, but they are still weak and not enough.

When comparing NSTQTM and EQUIS, the curriculum in EQUIS has been designed under the guidance of internationalization, ethics, responsibility \& sustainability, corporate connections; these three dimensions have been incorporated into the courses.[23] Liverpool Business School (LBS) in Liverpool John Moores University, a member of the EQUIS can be taken as an example; the core courses in LBS have placed more emphasis on internationalization and field specialties than NSTQTM has. They have provided courses such as international tourism business, tourism dynamics, tourism and hospitality in society, work related learning, investigative tourism, international tourism application, integrated marketing communications for tourism, individual research project, responsible tourism and planning, enterprise and entrepreneurship for tourism, international marketing, etc.,[24] which have placed emphasis on conformation to the latest requirements of professions and internationalization in the academic framework. Whereas courses in the general core of NSTQTM are travel management, hotel management, tourism hospitality, destination management, and travel consumption behavior. For the tourism management major, additional sub-core 
courses for tourism management major are tourism economy, tourism planning and development of tourism regulations, and additional sub-core courses for hotel management major are an introduction to hotel management, hotel operations management and hotel customer management. There are some differences in submajors, but there have been no courses related to internationalization development, personnel quality development, enterprise and society, etc. In NSTQTM, the updated requirements for the profession and for internationalization have not obviously been stated in the academic framework. While in YAU, there are only three teachers have overseas education background, the English abilities of the teaching team are weak. No bilingual professional courses have been provided. No original English textbooks have been used for teaching. It is still far away from international education.

Effectively absorbing the contents from the AACSB and EQUIS accreditation, drawing on the strengths of both to complement the Chinese NSTQTM can upgrade the professional standards of NSTQTM, talent education objectives, education specifications, teachers, educational conditions, quality assurance system, curriculum, professional curriculum structure, teacher composition. Effectively integrating China and international standards of higher education in tourism will promote the internationalization level of Yunnan higher education in tourism and meet the regional industry demands for tourism talents.

\section{CONCLUSION}

In order to comprehensively cultivate and enhance the overall quality and core competitiveness of Yunnan higher education in tourism, Yunnan tourism higher education should rely on NSTQTM as the basis and refer to the AACSB and EQUIS standards to integrate domestic and foreign educational resources with the aim of improving education quality, Yunnan colleges and universities should also set up scientific expertise and technical modules that not only meet international standards but also meet the needs of tourism industrial development, in accordance with the implementation of "Building a South and Southeast Asia Radiation Center" required by the central government.

\section{ACKNOWLEDGMENT}

Thanks to Mr. Zhai and Allen for their suggestions on revising this paper. Without their help, this article could not be finished and published.

\section{REFERENCES}

[1]Zhu, Hai, “Taking the 'One Belt and One Road' as an opportunity, Yunnan pragmatically promotes crossborder tourism cooperation," Yunnan Daily, July, 2017. DOI:http://yunnan.cn/html/2017-07/03/content _4873469.htm

[2]Liu, Hui, “China-ASEAN Expo tourism exhibition will be held in October, 'One Belt One Road' promotes the formation of a new mechanism for tourism cooperation," China Economic Times, August 2019. DOI:https://baijiahao.baidu.com/s?id=16419492549968 $53568 \& w f r=$ spider $\&$ for $=p c$

[3]Yang, Hongbo, "Seventy years, Yunnan has achieved positive results in the construction of a radiation center in South and Southeast Asia," China Development Network, January 2020. DOI:http://baijiahao.baidu.com /s?id=16437847610232 08565\&wfr=spider \&for $=$ pc

[4]Li, Ruixia, "Southeast Asia regional tourism cooperation and yunnan tourism development," Southeast Asia South Asia Research, (Z1), pp.45-48 December 2007. DOI:CNKI:SUN:DNYA.0.2007-Z1009 .

[5]Xinhua News Agency, "Xi Jinping stressed during his visit to Yunnan that we should resolutely fight the fight against poverty, and accelerate the economic and social development of ethnic areas," Xinhua News, January 2015. DOI:https://china.huanqiu.com/article /9CaKrnJGWdB

[6]Sang, Xia, "Discussion on the reform and development of higher education in tourism in China, Journal of Hubei Institute of Science and Technology, vol. 39, no.2, pp.33-37, April 2019.

DOI:10.16751/j.cnki.hbkj.2019.02.007

[7]Long, Runxiang, and Wang, Meiping, and Liang, Lei, "Research on the professional development of tourism higher education teachers," Teacher Construction, pp.107-108, May 2015. DOI:10.13615/j.cnki.1004-3985.2015.05.048

[8]Qiu Zhang, H., Lam, T. And Bauer, T., "Analysis of training and education needs of mainland Chinese tourism academics in the twenty-first century", International Journal of Contemporary Hospitality Management, vol.13, no.6, pp. 274-279, November 2001, DOI:10.1108/EUM0000000005969

[9]Peng, Li, "Problems and Development Ideas of China's Higher Education in Tourism," Tourism 
Research, pp.44-48, January 2010. DOI:CNKI:SUN:LYXJ.0.2010-00-010.

[10]Zhou, Fuguang, "An analysis of the high-quality development of tourism majors in higher vocational colleges in Fujian province - based on the perspective of new changes in the demand for tourism talents," Journal of Zhangzhou Institute of Technology, vol. 23, pp.6667, September 2021.DOI: 10.13908/j.cnki.issn16731417.2021.03.0010.

[11]Shen, Yafei, and Ma, Lihui, "Analysis of the influence factors of undergraduate professional identification in tourism," Journal of Heilongjiang Ecological Engineering Vocational College,vol.33, pp.113-115, January 2020.

DOI:CNKI:SUN:HSGX.0.2020-01-035.

[12]Yu, Junfang, "Confidence crisis caused by internship and prevention and control countermeasures based on a survey of applied tourism undergraduate students," Journal of Hubei University of Arts and Science, vol. 40, no. 9, pp.82-85, September 2019. DOI:CNKI:SUN:XFXY.0.2019-09-016.

[13]Xiao, Yunmin, "Suggestions on improving the effectiveness of internship practice for tourism management majors in higher vocational colleges taking Chongqing tourism vocational college as an example," Vocational Education, vol.18, no.2, pp.18-20, February 2019. DOI:CNKI:SUN:ZDZJ.0.2019-02-005.

[14]Jiang, Jingjing, "Implementation Path of Teaching Reform of Tourism Management Specialty in Private Colleges and Universities under the Background of 'Double Innovation'”, ZhiKu Era,vol.24, pp.47+51, June 2019. DOI:CNKI:SUN:ZKSD.0.2019-24-033.

[15]Huang, Yanling,miao, Yucong, and Luo, Shenfeng, "Analysis of the Construction of Undergraduate Curriculum System in Tourism under the Background of Digital Economy--Taking the Intelligent Tourism Management Major as an Example," Modern Education, no.11, pp.140-144+150, November 2019.

DOI:10.13980/j.cnki.xdjykx.2019.11.025.

[16]Yuan, Yingjie, "Research on the training of 'dual competency' talents for professional teacher capital in tourism management and service education," Yunnan University, MA thesis, March 2018. DOI:

https://kns.cnki.net/KCMS/detail/detail.aspx?dbname $=\mathrm{C}$ MFD202001\&filename $=1018246563 . \mathrm{nh}$

[17]Yi, Jidong, "Practical exploration for the training of international talents in Southeast Asia," China Higher
Education, no.12, pp.50-51, June 2009. DOI:CNKI:SUN:ZGDJ.0.2009-12-023.

[18]Xu, Nanyuan, “Accelerating training of tourism professionals to promote sustaionable development of tourism industry in Yunnan province," Journal of Yunnan Finance and Trade Institute, vol.16, no.3, pp.69-71, June 2000.

DOI:10.16537/j.cnki.jynufe.2000.03.017.

[19]Zhang, Yuzhen, "Yunnan tourism talent development status and countermeasures," Cooperative Economy and Science and Technology, no 3x, pp. 18120, March 2019.

DOI:10.13665/j.cnki.hzjjykj.2019.06.044.

[20] Higher Education Teaching Steering Committee of Ministry of Education, "National standards for undergraduate professional, teaching quality in ordinary colleges and universities," High Education Press, April 2018. ISBN: 978-7-04-049532-4.

DOI:https://jykxyjy.jsu.edu.cn/info/1464/2999.htm

[21] Ministry of Education of the People's Republic of China, "Introduction to the 'National Standards for Undergraduate Professional Teaching Quality in Colleges and Universities"', January 2018. DOI: http://www.moe.gov.cn/jyb_xwfb/xw_fbh/moe_2069/x wfbh_2018n/xwfb_20180130/sfcl/201801/t20180130_3 25921.html

[22]2013 Eligibility procedures and accreditation standards for business, accreditation, DOI: https://www.aacsb.edu//media/documents/accreditation/2018-businessstandards.pdf?la $=$ en

[23]EQUIS standards \& criteria, DOI: https://www.efmdglobal.org/wpcontent/uploads/2018_EQUIS_Standards_and_Criteria. pdf

[24] "What you will study on this degree", BA (hons) international tourism management with foundation year, Liverpool John Moores University, Liverpool Business School, https://www.ljmu.ac.uk/aboutus/faculties/faculty-of-business-and-law/liverpoolbusiness-school/courses 